\title{
Exploring the role of service quality, atmosphere and food for revisits in restaurants by using a e-mystery guest approach
}

\author{
Bernhard Fabian Bichler, Birgit Pikkemaat and Mike Peters \\ Department of Strategic Management, Marketing and Tourism, SME and Tourism, \\ University of Innsbruck, Innsbruck, Austria
}

Role of quality for revisits in restaurants

Received 15 April 2020 Revised 9 June 2020 7 July 2020 15 July 2020 Accepted 15 July 2020

\begin{abstract}
Purpose - Quality in foodservices has become essential, and new methodological ways of determining service quality enable a better representation of service processes and help to increase revisits. This paper focuses on the foodservice context and explores the relationship between staff-related service dimensions, atmosphere, food quality and revisit in a full-service setting.

Design/methodology/approach - This study combines an often neglected mystery guest approach with partial least square-structural equation modeling (PLS-SEM) to shed more light on customers' service perceptions. The mystery guest approach has been updated with a digitally supported smartphone questionnaire (e-mystery) that provides more reliable results since previous measurements experienced difficulties of feasibility in time-limited settings $(N=247)$.

Findings - The findings of this study confirm the direct effects of the service quality dimensions reliability, attentiveness and atmosphere on revisit intention and highlight the mediating role of food quality. In detail, the findings showed significant results for service employees' reliability and attentiveness and underlined the role of atmosphere for revisit intention.

Originality/value - The contribution of this paper supplements that mystery guest approaches represent a reliable alternative to convenience sampling, especially in combination with a digitally supported questionnaire (e-mystery). Thereby, this paper suggests the further application of e-mystery for the hospitality and tourism industry. In terms of implications, this study highlights the importance of securing food quality by fostering specialized schools and training programs for career starters. Since the findings stress the importance of service quality and atmosphere, managers need to ensure that employees are trained in culturally sensitive communication and services to excel in service-related dimensions.
\end{abstract}

Keywords Foodservice, Service quality, Food quality, Restaurants, Mystery guest, Revisit

Paper type Research paper

\section{Introduction}

Food experiences represent a crucial component of tourism, contributing to tourist expenditures and overall satisfaction of traveling (McKercher et al., 2008). In this context, quality dimensions are accepted as a key to achieving competitive advantages in foodservices. Crick and Spencer (2011, p. 466) highlighted that "organisations (. . .) need to understand with as much precision as possible what the guests want from the service

(C) Bernhard Fabian Bichler, Birgit Pikkemaat and Mike Peters. Published by Emerald Publishing Limited. This article is published under the Creative Commons Attribution (CC BY 4.0) licence. Anyone may reproduce, distribute, translate and create derivative works of this article (for both commercial and non-commercial purposes), subject to full attribution to the original publication and authors. The full terms of this licence may be seen at http://creativecommons.org/licences/by/4.0/legalcode.

The authors would like to thank the Austrian Federal Economic Chamber (WK Tirol) for supporting this project, as well as Ass.-Prof. Dr. Günther Botschen who provided insight and expertise that greatly assisted the research.

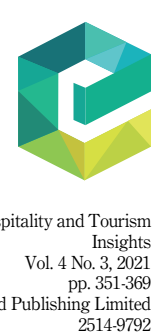

DOI 10.1108/JHTI-04-2020-0048 
JHTI

4,3

experience." Particularly in the foodservice context, customers have various choices between different restaurants, which could result in restaurants switching if expectations are not met (Stevens et al., 1995; Park and Jang, 2014b). Choice and quality of food, service, price, as well as atmosphere, are often seen as the main focus of restaurants. Still, foodservices do not solely concentrate on these attributes, but instead offer holistic dining experiences (Yuksel et al., 2010). An essential element of these experiences is service quality (SQ), which is intangible, individualized and subjective by nature (Chow et al., 2007). Therefore, restaurants try to optimize customer experiences by managing specific factors of total quality management (Psomas and Jaca, 2016).

There exist several schools of thought, which have defined quality dimensions differently (Parasuraman et al., 1988; Grönroos, 1984). The bottom line is that SQ consists of multiple dimensions, which can be classified as functional and technical (Grönroos, 1984) or interactional quality (Brady and Cronin, 2001). Crick and Spencer (2011) synthesized that satisfaction with the (service) product and the way the front-line staff delivered it are the minimum requirement. SQ is recognized to be a significant determinant of a company's success and therefore represents a major research stream of hospitality research (Bouranta et al., 2009; Bujisic et al., 2014).

Previous literature summarized the role of service, food and environment for customers' satisfaction and behavioral intentions (Shahzadi et al., 2018; Ryu et al., 2012). Crick and Spencer (2011) called for a better recognition of each sector's nuances in determining SQ, supported by the call of Shahzadi et al. (2018) for more comparative studies. Therefore, this paper sheds more light on foodservices in the small but highly touristic city of Innsbruck, Austria. Due to the long tradition in the foodservice and hospitality industry and the legal requirements (WKO, 2020), this study uses an adjusted set of measures and applies e-mystery to avoid convenience sampling. The e-mystery also accounts for the importance of assessing quality continuously throughout the service process (Crick and Spencer, 2011). E-mystery allows us to mirror and observe customers' service perceptions throughout the service delivery process: customers can evaluate services immediately, in real time during the service experience without introducing bias by evaluations after the service delivery process. The objective of this paper is to explore the relationship between staff-related service dimensions, atmosphere, food quality and revisit in a full-service setting. In this context, e-mystery enables to benchmark foodservice performance, which is difficult due to the intangible, perishable and inseparable nature of services (Ladhari, 2009).

\section{Theoretical perspectives}

\subsection{Service dimensions and revisit intention}

Numerous studies show that behavioral intentions refer to positive word of mouth resulting in recommendations, remaining loyal and revisits (Shahzadi et al., 2018; Jani and Han, 2011). Following the early work of Berry et al. (2002) on how to manage service experience with food quality (functional clue), SQ (humanic clue) and atmosphere (mechanic clue) as key attributes, revisits have been discussed extensively in the foodservice context (Karamustafa and Ülker, 2020; Nguyen et al., 2018; Bujisic et al., 2014; Ryu et al., 2012). Satisfaction and behavioral intentions are often used as dependent variables and in this context, previous research underlined the mediating role of satisfaction for customers' intentions (Barber et al., 2011; Lee and Whaley, 2019). Measuring revisit intention is important since behavioral intentions represent the likelihood to engage in a particular behavior (Oliver, 2014). Therefore, SQ is directly related to customer satisfaction and affects customers' intentions and thereby company's success (Gupta et al., 2007). 

quality for the foodservice industry (Shahzadi et al., 2018; Park and Jang, 2014a; Bujisic et al., 2014; Ryu et al., 2012). Grönroos (1984) separates quality dimensions into technical (e.g. food quality, meal) and functional quality, where the latter is more concerned about the service delivery process, personal contact and the atmosphere. Due to the intangible nature of the service process, the evaluation of the functional quality is highly subjective compared to food quality where a more objective assessment is possible. Later, the three-factor model by Brady environment quality and outcome quality, which have proven to be positive predictors of SQ.

Several scholars focused on the crucial role of food quality for customers' satisfaction and intentions (Shahzadi et al., 2018; Njite et al., 2015), while others emphasized the importance of SQ (Nguyen et al., 2018). In this context, previous research stressed the intangible, perishable and inseparable nature of services (Ladhari, 2009). These characteristics make it difficult for service providers to assess their performance, especially given the facts that service performance can only be assessed after the service has been received and because of its heterogeneous nature, quality can also vary in terms of day, place and customer (Parasuraman et al., 1988).

Customer's perception of SQ is defined as the customer's judgment of the superiority of the service (Zeithaml, 1988), which results from the comparison of the expected service and the actual perceived service performance (Ladhari, 2009; Oliver, 2014). In this context, SERVQUAL-related approaches, based on disconfirmation theory, made a significant contribution to consumer research in the service industry (Parasuraman et al., 1988). It consists of five dimensions to measure SQ: reliability, responsiveness, empathy, tangibles and assurance. Currently, these five dimensions still play an essential role in explaining SQ (Karamustafa and Ülker, 2020; Bilgihan et al., 2018; Liu and Tse, 2018).

\subsection{Service quality in restaurants}

A number of studies highlighted the applicability of SERVQUAL instruments such as DINESERV (Stevens et al., 1995), DINESCAPE (Ryu and Jang, 2008) or TANGSERV (Raajpoot, 2002) for foodservices. All these instruments capture different dimensions of quality and differ according to whether they are full service (Park and Jang, 2014a; Ryu et al., 2012; Jani and Han, 2011) or quick service (Nguyen et al., 2018; Etemad-Sajadi and Rizzuto, 2013; Richardson et al., 2019). Depending on the research focus, research highlighted either the importance of staff-related SQ, food quality or environmental factors such as ambiance. Previous studies showed that food quality is the most important aspect for customers' total quality perceptions of full-service restaurants (Shahzadi et al., 2018) but SQ is experiencing a revival in times of increased emphasis on customer experiences permeating marketing, economics, hospitality and psychology literature (Adhikari and Bhattacharya, 2016). In this context, recent literature highlighted the importance of customer experiences for the service industry (Teixeira et al., 2012; Dong and Siu, 2013; Brunner-Sperdin et al., 2012; Kim et al., 2017; Alhelalat et al., 2017). Additionally, it is noted that customer experience management represents an opportunity to achieve a competitive advantage in service organizations (Teixeira et al., 2012; Pikkemaat and Zehrer, 2016).

Tucker (1991) understood the speed of service delivery, convenience, value-adding, lifestyle connotations as well as the technology as influencing factors on customers' perceptions of the service experience. These aspects are closely related to staff-related SQ dimensions focusing on employees' reliability, responsiveness, empathy and assurance. In this context, Luo et al. (2019, p. 469) emphasized the role of "professionalism, the ability to respond to customers' emotions and hidden needs and build bonds with them, and the ability to deliver one-stop service" to achieve delightful service. 
JHTI

4,3

Additionally, previous research also showed the role of atmosphere for customers' behavioral intentions, for example, as underlined by the atmosphere dimension in the SERVQUAL and DINESERV measurements (Ladhari, 2009; Stevens et al., 1995) or by assessing the importance of ambiance (Sester et al., 2013; Njite et al., 2015). Other findings provide a more nuanced view on how cleanliness affects quality perceptions (Barber et al., 2011) or argue for the importance of music, temperature or aroma for emotional arousal, which also affects customers' intentions (Ryu et al., 2012). Therefore, the following hypotheses were developed:

H1. (a) Reliability, (b) attentiveness, (c) responsiveness and (d) atmosphere are positively related to customers' revisit intention.

Several researchers applied the SQ approach to foodservices, focusing on the gap between expectations and perceptions (Shahzadi et al., 2018). Rather subjective service attributes have also been modified by some researchers to fit the restaurant industry (Johns and Pine, 2002). Stevens et al. (1995) developed the DINESERV model by using the five dimensions of Parasuraman et al. (1988) but modified several items according to the restaurant sector in order to measure SQ as perceived by customers. Therefore, perceived SQ plays an important role when determining customer satisfaction as well as behavioral intentions. The following hypothesis were proposed:

H2. The higher the customers' perception of (a) reliability, (b) attentiveness, (c) responsiveness and (d) atmosphere, the higher the customers' perception of food quality.

\subsection{Food and atmosphere in restaurants}

Previous research discussed SQ, food quality and atmosphere as main drivers of behavioral intentions in the restaurant context (Namkung and Jang, 2008; Shahzadi et al., 2018). Specifically, research revealed that food quality predicts both patronage and willingness to pay in the restaurant context (Njite et al., 2015; Sulek and Hensley, 2004). Yuksel et al. (2010) found evidence that $\mathrm{SQ}$, followed by product quality, has the most significant effect on dining satisfaction. In contrast, Sulek and Hensley (2004) highlighted food quality as the most important factor influencing customers. Importantly, there are many different ways of conceptualizing food quality, ranging from taste and price to visuals and safety (Namkung and Jang, 2007). Thus, the following hypotheses were derived:

H3. Food quality is positively related to customers' revisit intention.

H4. The relationship between (a) reliability, (b) attentiveness, (c) responsiveness and (d) atmosphere and revisit intention is mediated by food quality.

Studies have identified several challenges associated with mystery guest approaches (Wiele et al., 2005). Thus, to control for potential biases, the following hypotheses were formulated:

H5. Mystery guests' characteristics such as (a) age, (b) gender, (c) accompany and (d) selfreported expertise and (e) self-reported stress levels correlate with perceived food quality.

H6. Mystery guests' characteristics such as (a) age, (b) gender, (c) accompany and (d) selfreported expertise and (e) self-reported stress levels correlate with revisit intention.

\section{Methodology}

Mystery guest approaches have been used in former studies in the travel and tourism industry (Liu et al., 2014; Anderson et al., 2001). They represent a special form of 
participant observation and require potential customers to evaluate service processes (Wiele et al., 2005). In a review on mystery shopping, Wilson (1998, p. 161) distills three possible applications: first, to act as a diagnostic tool identifying failings and weak points in an organization's service delivery; second, to encourage, develop and motivate service personnel by linking with appraisal, training and reward mechanisms; third, to assess the competitiveness of an organization's service provision by benchmarking it against the offerings of others in an industry. Wiele et al. (2005) add that mystery approaches can also be used to measure the effectiveness of (training) programs and to test if customers experience equal treatments. Despite the benefits of mystery shopping approaches such as less external pressure compared to traditional questionnaires, mystery shopping is a sensitive topic as it includes a high degree of knowledge asymmetry between customers and staff (Wiele et al., 2005). Additionally, training and briefing of mystery guests are essential to establish the reliability of mystery approaches (Wilson, 1998). While Morrison et al. (1997) highlighted issues, which occur from encoding, memorizing and retrieving information for service evaluations, these issues were counteracted with the e-mystery approach. Mysterious guests were able to fill out their ratings in real time via an online questionnaire on their mobile phones.

\subsection{Sampling}

As previous research has shown several tensions arising from mystery guest approaches, such as ethics of participant observation and the reliability of mystery shopping approaches (Wilson, 1998), particular attention was paid to the selection and preparation/training of mystery guests. Table 1 provides several key characteristics of the 66 mystery guests who were selected based on demographics and foodservice expertise. These mystery guests were identified by using a snowball sampling approach (Gobo, 2005), starting with research assistants and extending it to colleagues and other contacts willing to participate. Importantly, they were trained to make sure they understood the procedures and to evaluate the SQ immediately after the termination of each service phase. In order to keep the task manageable, mystery guests were instructed to test alone, in a group of two or a larger group.

Additionally, the study controlled for mystery guests' age, gender, self-reported stress level, accompany and previous experiences. For the initial identification of the businesses, a list of all gastronomic enterprises provided by the Austrian Federal Economic Chamber (WK Tirol) was used. The research team identified a set of well-known foodservice businesses by using purposive sampling. Mystery guests were randomly assigned (Gobo, 2005) to the selected enterprises and instructed to visit at different times of the day. There were no restrictions on the orders and the WK Tirol reimbursed the expenditures. The e-mystery questionnaires were filled out from November 2017 to December 2017 in the city of Innsbruck, Austria. Each of the mystery guests tested between two (minimum or $3.2 \%$ of visits) and eight (maximum or $6.4 \%$ of visits) foodservice businesses. On average, the businesses were visited four times, with a minimum of three and a maximum of six visits. Table 1 provides an overview of the mystery guests' characteristics.

\subsection{Measurements}

The measurements aimed to assess quality dimensions in the foodservice context. Literature acknowledged several issues concerning the feasibility (e.g. takes too long to fill out) of previous measurement scales (Sulek and Hensley, 2004). In combination with the e-mystery approach, which enables a real-time assessment of the service experiences during the service encounter, measurements were tailored to the specific requirements of the mystery guest approach and the nuances of the sector (Crick and Spencer, 2011). A systematic assessment of
Role of quality for revisits in restaurants 


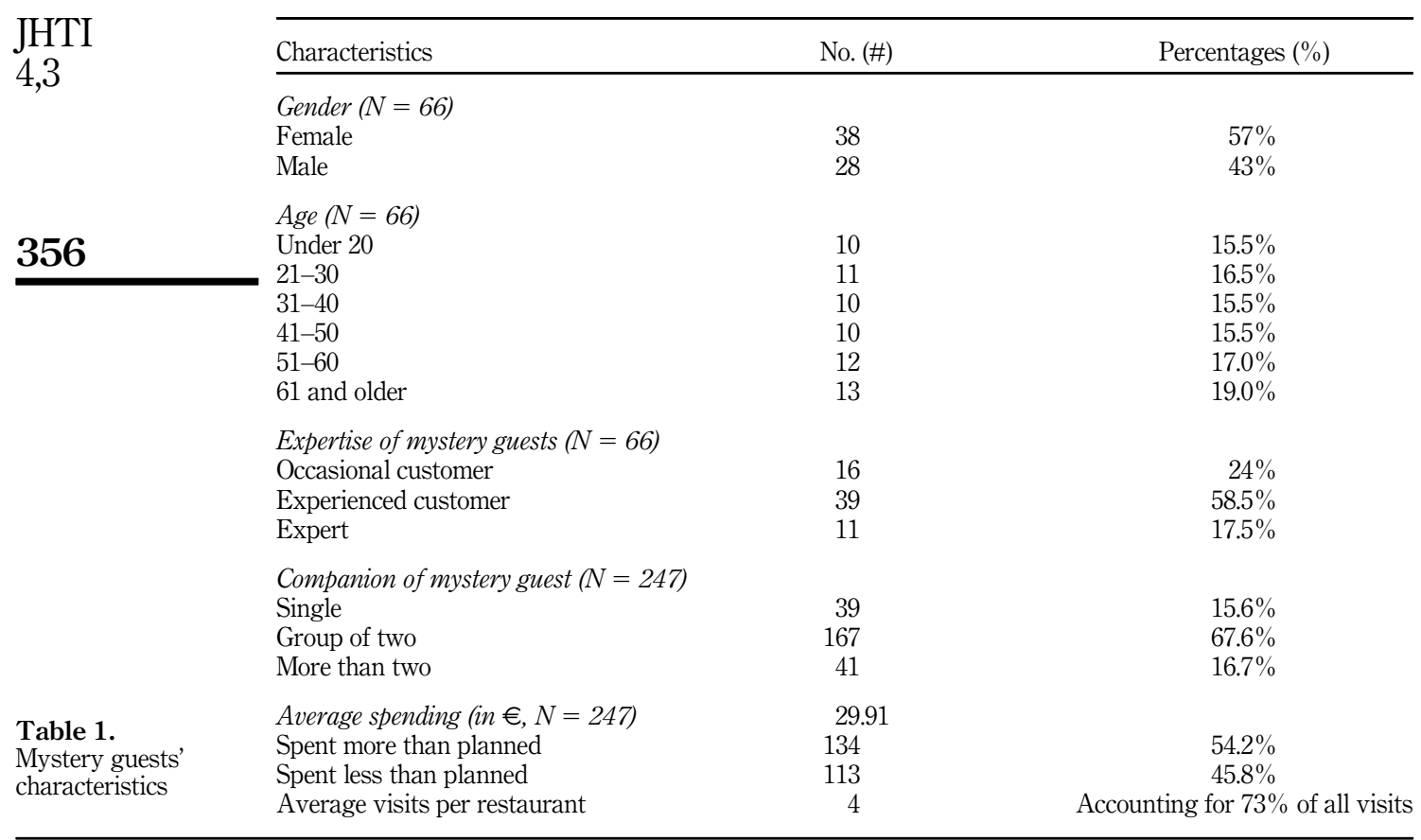

previously used constructs and items helped to synthesize the measures for the mystery guest approach (list of measures see Table A1).

After discussions within the research team, we decided to exclude assurance (Parasuraman et al., 1988) as a quality dimension. The paper is based on the full-service foodservice sector in Innsbruck (Austria), where commercial law and other requirements such as operating licenses are incredibly challenging (WKO, 2020) and the assurance dimension is more suitable for the banking and retailing industry (Parasuraman et al., 1988). Generally speaking, in the full-service foodservice context, orders are served directly to the table and the offer ranges from casual family restaurants to fine dining. Additionally, the selected full-service companies were similar regarding employees' knowledge and the degree of professionalization due to location and size. In addition, previous studies recognized time and cost efficiency as a central aspects in collecting mystery guest data (Sulek and Hensley, 2004).

The final instrument included 21 items to assess quality dimensions. These items were measured on a Likert Scale, ranging from "strongly disagree" (1) to "strongly agree" (5). Additionally, data was collected on the characteristics of the mystery guests, such as age, gender, accompany, expertise and stress levels. Single-item self-reported measures were used to ask respondents whether they consider themselves (1) "occasional", (2) "experienced customers" or (3) "expert customers" and to rate their self-reported stress levels on a scale from (1) "relaxed" to (3) "stressed" for each service setting. Based on previous literature supporting the role of revisit and recommend intention as a proxy for loyalty (Jani and Han, 2011), a combination of revisit and recommend intention was used due to time constraints connected with the mystery guest approach as a dependent variable (Kivela et al., 1999; Getty and Thompson, 1995). 


\subsection{Data analysis}

First, exploratory factor analysis (EFA) was used to identify the underlying factors. Both the Kaiser-Meyer-Olkin (KMO) measure of sampling adequacy (0.886) and the Bartlett test of sphericity (1504.826***) indicated the suitability of EFA. Factors exceeding 0.60 were retained (Hair et al., 2012). Moreover, Cronbach's alpha was used to assess internal validity and ranged between 0.583 and 0.878 . Second, partial least square-structural equation modeling (PLSSEM) in SmartPLS ${ }^{\mathrm{TM}}$ (v. 3.2.8) was used to analyze the data (Ringle et al., 2015). This "soft modeling approach" (Hair et al., 2012, p. 416) has several advantages, such as that it can be used with less rigid theoretical backgrounds and for prediction-oriented research aimed at maximizing the explained variance of dependent variables (Hair et al., 2012; Henseler et al., 2014). This approach does not require normally distributed data and is well suited for smaller sample sizes (Henseler et al., 2014). In combination with the e-mystery approach, it represents a straightforward approach to explore the relationship in greater depth.

\section{Results}

\subsection{Reliability, validity and common method bias analyses}

PLS-SEM was used (Hair et al., 2012) to assess the relationships among the constructs. First, validity and reliability were assessed by using composite reliability (CR) and average variance extracted (AVE). One item was excluded since the factor loading did not exceed 0.60. The Fornell-Larcker ratio (Fornell and Larcker, 1981) showed that the square roots of the AVEs are greater than the construct correlations. Additionally, cross-loadings were not a significant concern for the data and all items loaded the highest on the proposed factor. Thus, the data indicated discriminant validity for the constructs. To test for common method variance, a common method factor (Podsakoff et al., 2003) following the procedure by Liang et al. (2007) was included. The constructs of the proposed model (Figure 1) explained on average 0.65 of indicator variance and showed high and significant loadings. In contrast, the common method factor only accounted for 0.03 of indicator variance on average and showed significant results only in six cases and smaller loadings (see Table A3). Since the ratio between substantive variance and method variance is $22: 1$, it was concluded that common method variance is not a serious concern for the data. Table 2 shows the identified factors, factor loadings, Cronbach's alpha, CR and AVE.

\subsection{Results and hypothesis testing}

The findings show that reliability $(M=4.37, \mathrm{SD}=0.71)$, food quality $(M=4.04, \mathrm{SD}=0.74)$ and responsiveness of staff $(M=4.01, \mathrm{SD}=1.02)$ scored high on the Likert scale (Table 2$)$.

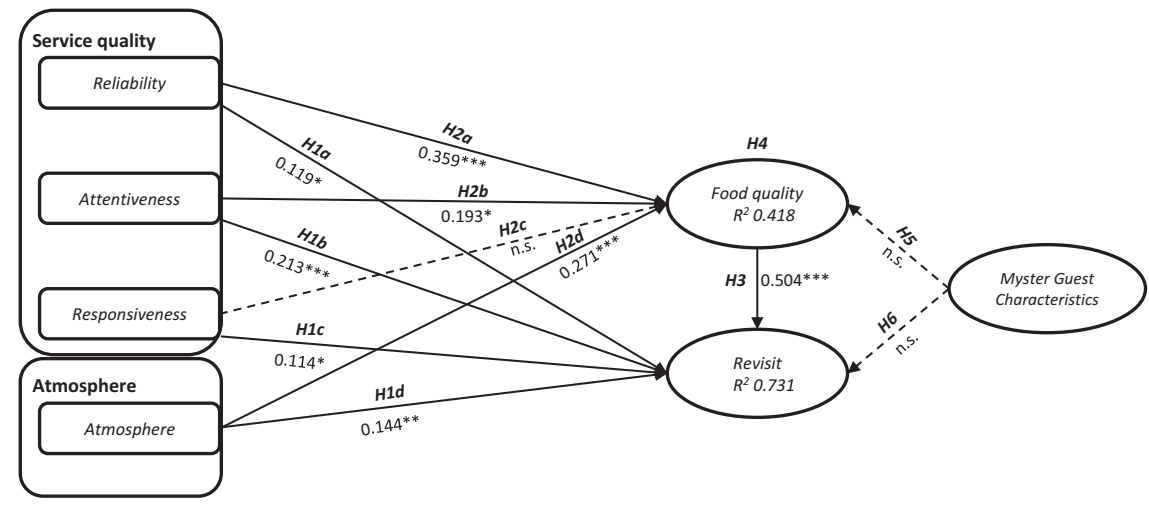

Role of quality for revisits in restaurants 


\section{JHTI 4,3}

358

\begin{tabular}{|c|c|c|c|}
\hline & $\begin{array}{c}\mathrm{EFA} \\
\text { loadings }\end{array}$ & $\begin{array}{c}\text { PLS-SEM } \\
\text { loadings (CR) }\end{array}$ & Mean (SD) \\
\hline Reliability & $\alpha=0.764$ & $\mathrm{CR}=0.852$ & $4.37(0.71)$ \\
\hline All ordered drinks were served quickly and perfectly & 0.759 & 0.779 & $4.43(0.79)$ \\
\hline $\begin{array}{l}\text { Delivery of all ordered drinks and food left nothing to be } \\
\text { desired }\end{array}$ & 0.707 & 0.767 & $4.42(0.80)$ \\
\hline The entire order was placed quickly and easily & 0.821 & 0.795 & $4.62(0.66)$ \\
\hline $\begin{array}{l}\text { I was able to order immediately after receiving the drinks/ } \\
\text { menu }\end{array}$ & 0.791 & 0.731 & $4.49(0.76)$ \\
\hline Attentiveness & $\alpha=0.878$ & $\mathrm{CR}=0.895$ & $3.45(1.05)$ \\
\hline $\begin{array}{l}\text { The attentive nature of the staff stimulated increased } \\
\text { consumption }\end{array}$ & 0.835 & 0.748 & 2.79 (1.31) \\
\hline The staff literally read the wishes from my eyes & 0.845 & 0.785 & $3.17(1.17)$ \\
\hline The staff asked if everything was for the best & 0.780 & 0.747 & 3.84 (1.34) \\
\hline $\begin{array}{l}\text { I felt warmly and professionally looked after during the } \\
\text { whole visit }\end{array}$ & 0.798 & 0.832 & $4.08(0.94)$ \\
\hline My waitress/waiter was especially attentive during the & 0.865 & 0.857 & $3.58(1.15)$ \\
\hline
\end{tabular}

whole visit

\section{Responsiveness}

I was immediately noticed

The welcome was very friendly

I was immediately offered a suitable place/table

\section{Atmosphere}

The atmosphere is pleasant

The areas are thoroughly clean

The other guests contributed to my well-being

\section{Food quality}

For this type of restaurant, the range of drinks and food leaves nothing to be desired

The sensory quality of food and beverages was excellent The price/performance ratio for the food/drinks offered is excellent

\section{Revisit}

I would recommend the restaurant because of the service experience

I would recommend this place because of the quality of the

Table 2. food/drinks

Factor analysis of SQ constructs
Based on all my experiences I would visit the restaurant again

$\begin{array}{ccc}\alpha=0.701 & \mathrm{CR}=0.856 & 4.01(1.02) \\ 0.844 & 0.845 & 4.45(0.89) \\ 0.786 & 0.740 & 3.81(1.48) \\ 0.817 & 0.856 & 4.14(0.95) \\ \alpha=0.583 & \mathrm{CR}=0.774 & 3.78(0.79) \\ 0.648 & 0.730 & 4.33(0.76) \\ 0.745 & 0.673 & 3.10(1.16) \\ 0.824 & 0.816 & 3.80(1.09) \\ \alpha=0.625 & \mathrm{CR}=0.804 & 4.04(0.74) \\ 0.706 & 0.757 & 4.11(0.96) \\ & & \\ 0.830 & 0.825 & 4.23(0.88) \\ 0.714 & 0.694 & 3.92(0.89) \\ & & \\ \alpha=0.852 & \mathrm{CR}=0.912 & 3.88(1.06) \\ 0.926 & 0.923 & 3.96(1.06) \\ 0.815 & & 4.18(1.03) \\ 0.897 & 0.823 & 3.85(1.27)\end{array}$

Lower but still high values were observed for attentiveness $(M=3.45$, SD $=1.05)$ and atmosphere $(M=3.78, \mathrm{SD}=0.79)$.

Figure 1 highlights the path coefficients, significance levels and $R^{2}$ values. Reliability $(\beta=0.119, p<0.05)$, attentiveness $(\beta=0.213, p<0.000)$, responsiveness $(\beta=0.114, p<0.05)$ and atmosphere $(\beta=0.144, p<0.001)$ contributed significantly to revisit. Hence, the analysis fully confirms hypotheses H1a to H1d. Reliability $(\beta=0.359, p<0.000)$, attentiveness $(\beta=0.193, p<0.05)$ and atmosphere $(\beta=0.271, p<0.000)$ were found to positively contribute to food quality, thereby fully supporting H2a, H2b and H2d. However, no effects on responsiveness were found and $\mathrm{H} 2 \mathrm{c}$ was therefore rejected. This is surprising but could be explained with potential confounding variables affecting the responsiveness construct. 
For example, in less formal foodservice settings in Austria, it is common to self-select a table and thus, future studies should consider this heterogeneity. H3 indicated a positive relationship between food quality and revisit, which was fully supported $(\beta=0.504, p<0.000)$.

To assess the mediation hypotheses, estimates and $T$-statistics for total, direct and indirect effects were calculated following the Preacher and Hayes (2008) procedure. To check for the significance of the mediation, the $95 \%$ bias-corrected confidence intervals were calculated, using 5,000 bootstrap samples (Table 2). The findings of the mediation analysis show that atmosphere $(\beta=0.139, p<0.000)$, attentiveness $(\beta=0.102, p<0.01)$ and reliability $(\beta=0.177, p<0.000)$ are partially mediated by food quality. This confirms hypothesis H4a, $\mathrm{H} 4 \mathrm{~b}$ and $\mathrm{H} 4 \mathrm{~d}$, but H4c is rejected since no effects were found. Following Hair et al. (2017), the findings show partial mediation since indirect and direct effects are both significant and in the same direction. Lastly, the influence of mystery guests' characteristics on food quality (H5) and revisit (H6) was assessed, but no significant effects for age, gender, stress level, accompany and expertise were found. Thus, H5a-H5e and H6a-H6e were rejected.

\section{Discussion and conclusions}

\subsection{Conclusions}

This paper highlights the importance of quality factors in the full-service foodservice industry. While staff-related SQ emerged as an important factor for revisit intention, the findings also highlighted the role of atmosphere and the mediating effects of food quality for revisits. These findings are essential since securing positive experiences leading to satisfaction and revisit is crucial for the success of foodservices. This study thus complements existing literature, which highlights the direct impact of functional quality on revisit intention (Luo et al., 2019), but also confirms studies that have shown the role of food quality in revisiting and satisfaction (Sulek and Hensley, 2004). In detail, the findings underline that food quality partially mediates the relationship between attentiveness, reliability and atmosphere (Table 3). Additionally, this paper also offers an important methodological contribution by emphasizing the potential of e-mystery guest approaches for future quality evaluations. Combining a traditional mystery guest approach (Wiele et al., 2005 ) with widely available mobile technology resulted in an e-mystery approach with realtime assessments, fixed time issues and showed an alternative to convenience sampling (Ryu et al., 2012; Sulek and Hensley, 2004).

\subsection{Theoretical implications}

The findings of this paper highlight five critical quality dimensions for foodservices. Consistent with previous studies, the findings show that SQ is a key requirement to ensure revisits (Gupta et al., 2007; Stevens et al., 1995). In particular, the findings highlight the importance of functional and staff-related factors such as attentiveness and reliability (Table 3). These findings correspond with Muskat et al. (2019), who demonstrated the importance of employee interactions for dining experiences. This also supports the early work of Grönroos (1984) and Brady and Cronin (2001), discussing the importance of functional and interactional quality.

In light of established theories, the findings provide several insights. Parasuraman et al. (2005) synthesize that "consumers retain product information in memory at multiple levels of abstraction" (2005, p. 217). From a means-end chain perspective, the findings allow a processoriented exploration of the importance of attributes (e.g. atmosphere), functional consequences (e.g. responsiveness and reliability) and psychological consequences (e.g. attentiveness) for value creation, which results in increased revisit intention. Second, in light of the theory of reasoned action (Ajzen and Fishbein, 1980), which aims to explore individuals' 


\begin{tabular}{|c|c|c|c|c|c|c|c|c|}
\hline \multirow[t]{5}{*}{4,3} & & Estimate & SE & $t$-value & \multicolumn{2}{|c|}{$\begin{array}{l}\text { Bias corrected } \\
95 \% \text { C.I. }\end{array}$} & \multirow{2}{*}{$\frac{p \text {-value }}{0.023}$} & \multirow{2}{*}{$\frac{\text { Decision }}{\text { Supported }}$} \\
\hline & H1a: Reliability $\rightarrow$ Revisit & 0.119 & 0.052 & 2.278 & & & & \\
\hline & H1b: Attentiveness $\rightarrow$ Revisit & 0.213 & 0.053 & 4.037 & & & 0.000 & Supported \\
\hline & H1c: Responsiveness $\rightarrow$ Revisit & 0.114 & 0.056 & 2.027 & & & 0.043 & Supported \\
\hline & H1d: Atmosphere $\rightarrow$ Revisit & 0.144 & 0.046 & 3.134 & & & 0.002 & Supported \\
\hline \multirow[t]{15}{*}{360} & H2a: Reliability $\rightarrow$ Food quality & 0.359 & 0.066 & 5.437 & & & 0.000 & Supported \\
\hline & H2b: Attentiveness $\rightarrow$ Food quality & 0.193 & 0.077 & 2.506 & & & 0.012 & Supported \\
\hline & H2c: Responsiveness $\rightarrow$ Food quality & -0.05 & 0.068 & 0.740 & & & 0.459 & Not supported \\
\hline & H2d: Atmosphere $\rightarrow$ Food quality & 0.271 & 0.066 & 4.110 & & & 0.000 & Supported \\
\hline & H3: Food quality $\rightarrow$ Revisit & 0.504 & 0.049 & 10.267 & & & 0.000 & Supported \\
\hline & H4a: Reliability $\rightarrow \mathrm{FQ} \rightarrow$ Revisit & 0.177 & 0.034 & 4.544 & 0.108 & 0.265 & 0.000 & Supported \\
\hline & H4b: Attentiveness $\rightarrow \mathrm{FQ} \rightarrow$ Revisit & 0.102 & 0.04 & 2.437 & 0.023 & 0.18 & 0.008 & Supported \\
\hline & H4c: Responsiveness $\rightarrow \mathrm{FQ} \rightarrow$ Revisit & -0.025 & 0.034 & 0.744 & -0.093 & 0.038 & 0.472 & Not supported \\
\hline & $\mathrm{H} 4 \mathrm{~d}:$ Atmosphere $\rightarrow \mathrm{FQ} \rightarrow$ Revisit & 0.139 & 0.033 & 4.205 & 0.073 & 0.202 & 0.000 & Supported \\
\hline & H5a: Age $\rightarrow$ Food quality & 0.025 & 0.05 & 0.503 & & & 0.615 & Not supported \\
\hline & H5b: Gender $\rightarrow$ Food quality & 0.048 & 0.056 & 0.860 & & & 0.390 & Not supported \\
\hline & H5c: Accompany $\rightarrow$ Food quality & 0.049 & 0.048 & 1.008 & & & 0.314 & Not supported \\
\hline & H5d: Stress level $\rightarrow$ Food quality & -0.043 & 0.056 & 0.769 & & & 0.442 & Not supported \\
\hline & H5e: Expertise $\rightarrow$ Food quality & 0.08 & 0.055 & 1.463 & & & 0.144 & Not supported \\
\hline & H6a: Age $\rightarrow$ Revisit & 0.017 & 0.032 & 0.542 & & & 0.588 & Not supported \\
\hline Table 3. & H6b: Gender $\rightarrow$ Revisit & 0.059 & 0.037 & 1.600 & & & 0.110 & Not supported \\
\hline Structural & H6c: Accompany $\rightarrow$ Revisit & 0.002 & 0.031 & 0.076 & & & 0.939 & Not supported \\
\hline relationships and & H6d: Expertise $\rightarrow$ Revisit & 0.04 & 0.031 & 1.275 & & & 0.202 & Not supported \\
\hline hypothesis decisions & H6e: Stress level $\rightarrow$ Revisit & 0.042 & 0.036 & 1.139 & & & 0.255 & Not supported \\
\hline
\end{tabular}

behavior in the purchase process, the findings highlight five factors (reliability, attentiveness, responsiveness, atmosphere and food quality) that can be used to explain this process in foodservices. Following these theoretical considerations, quality assessments result from the evaluation of upstream factors, which emphasize the role of intangible experiences such as attention and reliability for service experiences in foodservices.

Additionally, it is also shown that customer's intention to revisit is affected by atmosphere (Figure 1), which consists of factors such as pleasant atmosphere and clean facilities (Table 2). In line with previous research, the importance of gastronomic environment and food sanitation as a basic requirement for customer satisfaction is confirmed (Liu and Jang, 2009; Han and Hyun, 2017). In the structural model, food quality was found to partially mediate the SQ-revisit relationship (Table 3). This also supplements previous studies (Luo et al., 2019; Erkmen; Hancer, 2019) on the importance of delightful service but also underlines the importance of food quality to achieve revisit. In summary, while much attention is given to service experiences and the service encounter, the findings highlight that the art of preparing excellent and tasty food should not be underestimated, as Bujisic et al. (2014) also reported for different types of restaurants. Also, Liu and Jang (2009) confirmed the importance of technical quality, service reliability and environmental cleanliness to secure satisfaction and achieve positive behavioral intentions. The results of this study underline that the quality of service encounters, which is in this study partially mediated by the food quality, significantly affects customers' behavioral intentions. This is also supported by Sulek and Hensley (2004), who showed that food quality was most important for return intention and satisfaction.

Regarding early research on SERVQUAL (Parasuraman et al., 1988) and DINESERV (Stevens et al., 1995), the results indicate that nowadays SQ has become a fundamental factor for foodservices due to increasing specialization and professionalization. Recently customers 
are more experienced in food quality and they search for atmosphere (Liu and Tse, 2018; Ryu et al., 2012). In the context of ethnic restaurants, Muskat et al. (2019) found proof that an authentic atmosphere plays an important role for satisfaction in Austrian ethnic restaurants.

Integrating e-mystery guest approaches for data acquisition allows collecting real-time data over a more extended period, which provides direct assessments of customers' experiences (Wilson, 1998). This provides an advantage in the evaluation of foodservices, where services and products are known to be heterogeneous, perishable and inseparable from the consumption process (Ladhari, 2009). The e-mystery approach results in direct evaluations of quality dimensions and no bias is introduced by filling out the questionnaire after finishing the visit. Nevertheless, the findings underline that research designs using mystery guest approaches need to pay special attention to the training and selection of mystery guests that often have varying degrees of expertise (Wiele et al., 2005).
Role of quality for revisits in restaurants

\subsection{Managerial implications}

Even though customers represent highly heterogeneous subgroups with different traits and characteristics (Ihtiyar et al., 2018), the findings of this study have important implications for the configuration of quality dimensions for foodservices. Improvements in the full-service food industry need to address staff-related factors, such as attention and reliability, but also factors that result as process outcomes (e.g. food quality). Since employees' interactions with guests contribute positively to enhance dining experiences (Muskat et al., 2019), it is necessary to train employees to stay connected with their guests (Luo et al., 2019). On the one hand, communication and emotional skills of employees seem to be of utmost importance to interact with guests and provide successful service processes (Lloyd and Luk, 2011; Mattila and Enz, 2002). On the other hand, an increasing number of cross-cultural service encounters occur, leading to the need to train employees for culturally sensitive communication and services in restaurants (Lee, 2015; Ihtiyar et al., 2019). Besides, environmental factors such as atmosphere have shown to positively affect customers' intentions but appear more challenging to manage (Liu and Tse, 2018). Restaurant managers need to be aware of dealing with and arranging the restaurant's environment, including factors such as atmosphere and target groups (Bilgihan et al., 2018). Recently, Karamustafa and Ulker (2020) report that restaurant attributes related to cleanliness were found to be the most important attributes when evaluated from foreigners in a tourism context. The ideal composition of ambiance, space and function as well as artifacts, signs or symbols forms a prerequisite for positive customer and employee experiences during the service process (Karamustafa and Ülker, 2020; Bujisic et al., 2014; Muskat et al., 2019; Nguyen et al., 2018).

Consequently, managers of restaurants should be able to deliver an appealing atmosphere for their target group, including light and sound solutions, an appropriate location with parking spaces and authentic menus of high quality (Muskat et al., 2019; Bilgihan et al., 2018). External knowledge from light and interior designers can deliver successful inputs as well as from restaurant consulters. Since the findings also highlight the mediating role of food quality, this also points out the importance of providing high-quality education for future chefs. This requires both specialized schools for career starters and further training opportunities for employees, who choose to engage in the foodservice industry on the second educational path.

\subsection{Limitations and future research}

This research includes several limitations. Although the mystery guest approach has shown to be valid and promising (Wilson, 1998), training and preparation remain essential. Since partial mediation was found, this indicates that there exist other potential mediators for the quality-revisit relationship (Hair et al., 2017). Thus, future research will be necessary to 
JHTI 4,3

362

examine possibly omitted mediators and moderators, also in other settings and locations. It will be necessary to extend and evaluate the findings of this paper in other studies using, for example, experimental approaches or a qualitative open critical incident technique to gather deeper insights and thick descriptions of service encounters in the foodservice sector. Additionally, the e-mystery guest approach provides vital insights into the performance of SQ and can be used to gather consumer-driven knowledge for future SQ studies. Lastly, future research needs to explore the role of service innovations (Pikkemaat et al., 2019; Pikkemaat; Zehrer, 2016) to improve quality perceptions and if conditions relating to experiences influence customers' behavior, for example, perceived authenticity of the employees or spoken languages.

\section{References}

Adhikari, A. and Bhattacharya, S. (2016), "Appraisal of literature on customer experience in tourism sector. Review and framework", Current Issues in Tourism, Vol. 19 No. 4, pp. 296-321.

Ajzen, I. and Fishbein, M. (1980), Understanding Attitude and Predicting Social Behavior, Prentice-Hall, Englewood Cliffs.

Albacete-Sáez, C.A., Mar Fuentes-Fuentes, M. and Javier Lloréns-Montes, F. (2007), "Service quality measurement in rural accommodation", Annals of Tourism Research, Vol. 34 No. 1, pp. 45-65.

Alhelalat, J.A., Habiballah, M.A. and Twaissi, N.M. (2017), "The impact of personal and functional aspects of restaurant employee service behaviour on customer satisfaction", International Journal of Hospitality Management, Vol. 66, pp. 46-53.

Anderson, D.N., Groves, D.L., Lengfelder, J. and Timothy, D. (2001), "A research approach to training. A case study of mystery guest methodology", International Journal of Contemporary Hospitality Management, Vol. 13 No. 2, pp. 93-102.

Barber, N., Goodman, R.J. and Goh, B.K. (2011), "Restaurant consumers repeat patronage: a service quality concern", International Journal of Hospitality Management, Vol. 30 No. 2, pp. 329-336.

Berry, L.L., Carbone, L.P. and Haeckel, S.H. (2002), "Managing the total customer experience", MIT Sloan Management Review, Vol. 43 No. 3, pp. 1-6.

Bilgihan, A., Seo, S. and Choi, J. (2018), "Identifying restaurant satisfiers and dissatisfiers. Suggestions from online reviews", Journal of Hospitality Marketing and Management, Vol. 27 No. 5, pp. 601-625.

Bouranta, N., Chitiris, L. and Paravantis, J. (2009), "The relationship between internal and external service quality", International Journal of Contemporary Hospitality Management, Vol. 21 No. 3, pp. 275-293.

Brady, M.K. and Cronin, J.J. (2001), "Some new thoughts on conceptualizing perceived service quality. A hierarchical approach", Journal of Marketing, Vol. 65 No. 3, pp. 34-49.

Brunner-Sperdin, A., Peters, M. and Strobl, A. (2012), "It is all about the emotional state: managing tourists' experiences", International Journal of Hospitality Management, Vol. 31 No. 1, pp. 23-30.

Bujisic, M., Hutchinson, J. and Parsa, H.G. (2014), "The effects of restaurant quality attributes on customer behavioral intentions", International Journal of Contemporary Hospitality Management, Vol. 26 No. 8, pp. 1270-1291.

Chow, I.H.-S., Lau, V.P., Lo, T.W.-C., Sha, Z. and Yun, H. (2007), "Service quality in restaurant operations in China: decision- and experiential-oriented perspectives", International Journal of Hospitality Management, Vol. 26 No. 3, pp. 698-710.

Crick, A.P. and Spencer, A. (2011), "Hospitality quality. New directions and new challenges", International Journal of Contemporary Hospitality Management, Vol. 23 No. 4, pp. 463-478.

Dong, P. and Siu, N.Y.-M. (2013), "Servicescape elements, customer predispositions and service experience: the case of theme park visitors", Tourism Management, Vol. 36, pp. 541-551. 
Erkmen, E. and Hancer, M. (2019), "Building brand relationship for restaurants”, International Journal of Contemporary Hospitality Management, Vol. 31 No. 3, pp. 1469-1487.

Etemad-Sajadi, R. and Rizzuto, D. (2013), "The antecedents of consumer satisfaction and loyalty in fast food industry", International Journal of Quality and Reliability Management, Vol. 30 No. 7, pp. 780-798.

Fornell, C. and Larcker, D.F. (1981), "Evaluating structural equation models with unobservable variables and measurement error", Journal of Marketing Research, Vol. 18 No. 1, pp. 39-50.

Getty, J.M. and Getty, R.L. (2003), "Lodging quality index (LQI). Assessing customers' perceptions of quality delivery”, International Journal of Contemporary Hospitality Management, Vol. 15 No. 2, pp. 94-104.

Getty, J.M. and Thompson, K.N. (1995), "The relationship between quality, satisfaction, and recommending behavior in lodging decisions", Journal of Hospitality and Leisure Marketing, Vol. 2 No. 3, pp. 3-22.

Gobo, G. (2005), "Sampling, representativeness and generalizability", in Seale, C., Gobo, G. and Gubrium, J.F. (Eds), Qualitative Research Practice, Sage, London, pp. 435-455.

Grönroos, C. (1984), “A service quality model and its marketing implications", European Journal of Marketing, Vol. 18 No. 4, pp. 36-44.

Gupta, S., McLaughlin, E. and Gomez, M. (2007), "Guest satisfaction and restaurant performance", Cornell Hotel and Restaurant Administration Quarterly, Vol. 48 No. 3, pp. 284-298.

Hair, J.F., Sarstedt, M., Ringle, C.M. and Mena, J.A. (2012), "An assessment of the use of partial least squares structural equation modeling in marketing research", Journal of the Academy of Marketing Science, Vol. 40 No. 3, pp. 414-433.

Hair, J.F., Hult, G.T.M., Ringle, C.M. and Sarstedt, M. (2017), A Primer on Partial Least Squares Structural Equation Modeling (PLS-SEM), 2nd ed., Sage, Los Angeles.

Han, H. and Hyun, S.S. (2017), "Impact of hotel-restaurant image and quality of physical-environment, service, and food on satisfaction and intention", International Journal of Hospitality Management, Vol. 63, pp. 82-92.

Henseler, J., Dijkstra, T.K., Sarstedt, M., Ringle, C.M., Diamantopoulos, A., Straub, D.W., Ketchen, D.J., Hair, J.F., Hult, G.T.M. and Calantone, R.J. (2014), "Common beliefs and reality about PLS", Organizational Research Methods, Vol. 17 No. 2, pp. 182-209.

Ihtiyar, A., Ihtiyar, H.G. and Galay, Y. (2018), "Exploration of the antecedents and consequences of customers' service experiences", Journal of Hospitality and Tourism Insights, Vol. 1 No. 4, pp. 367-386.

Ihtiyar, A., Aras, O.N. and Öztürk, M. (2019), "A quantitative analysis of intercultural communication and personality. The case of coffee shop consumers in Cambodia", in Rezaei, S. (Ed.), Quantitative Tourism Research in Asia, Perspectives on Asian Tourism, Springer, Singapore, Vol. 25, pp. 149-188.

Jani, D. and Han, H. (2011), "Investigating the key factors affecting behavioral intentions", International Journal of Contemporary Hospitality Management, Vol. 23 No. 7, pp. 1000-1018.

Johns, N. and Pine, R. (2002), "Consumer behaviour in the food service industry. A review", International Journal of Hospitality Management, Vol. 21 No. 2, pp. 119-134.

Karamustafa, K. and Ülker, P. (2020), "Impact of tangible and intangible restaurant attributes on overall experience: a consumer oriented approach", Journal of Hospitality Marketing and Management, Vol. 29 No. 4, pp. 404-427.

Kim, J.-H., Youn, H. and Rao, Y. (2017), "Customer responses to food-related attributes in ethnic restaurants”, International Journal of Hospitality Management, Vol. 61, pp. 129-139.

Kivela, J., Inbakaran, R. and Reece, J. (1999), "Consumer research in the restaurant environment, Part 1: a conceptual model of dining satisfaction and return patronage", International Journal of Contemporary Hospitality Management, Vol. 11 No. 5, pp. 205-222.
Role of quality for revisits in restaurants 
JHTI 4,3

Ladhari, R. (2009), “A review of twenty years of SERVQUAL research", International Journal of Quality and Service Sciences, Vol. 1 No. 2, pp. 172-198.

Lee, H.E. (2015), "Does a server's attentiveness matter? Understanding intercultural service encounters in restaurants", International Journal of Hospitality Management, Vol. 50, pp. 134-144.

Lee, W.-H. and Cheng, C.-C. (2018), "Less is more: a new insight for measuring service quality of green hotels", International Journal of Hospitality Management, Vol. 68, pp. 32-40.

Lee, J. and Whaley, J.E. (2019), "Determinants of dining satisfaction”, Journal of Hospitality Marketing and Management, Vol. 28 No. 3, pp. 351-378.

Liang, H., Saraf, N., Hu, Q. and Xue, Y. (2007), "Assimilation of enterprise systems. The effect of institutional pressures and the mediating role of top management", MIS Quartely, Vol. 31 No. 1, pp. 59-87.

Liu, Y. and Jang, S. (2009), "Perceptions of Chinese restaurants in the US What affects customer satisfaction and behavioral intentions?", International Journal of Hospitality Management, Vol. 28 No. 3, pp. 338-348.

Liu, P. and Tse, E.C.-Y. (2018), "Exploring factors on customers' restaurant choice. An analysis of restaurant attributes", British Food Journal, Vol. 120 No. 10, pp. 2289-2303.

Liu, C.-H.S., Su, C.-S., Gan, B. and Chou, S.F. (2014), "Effective restaurant rating scale development and a mystery shopper evaluation approach", International Journal of Hospitality Management, Vol. 43, pp. 53-64.

Lloyd, A.E. and Luk, S.T.K. (2011), "Interaction behaviors leading to comfort in the service encounter", Journal of Services Marketing, Vol. 25 No. 3, pp. 176-189.

Luo, C.-C., Wang, Y.-C. and Tai, Y.-F. (2019), "Effective training methods for fostering exceptional service employees", Journal of Hospitality and Tourism Insights, Vol. 2 No. 4, pp. 469-488.

Mattila, A.S. and Enz, C.A. (2002), "The role of emotions in service encounters", Journal of Service Research, Vol. 4 No. 4, pp. 268-277.

McKercher, B., Okumus, F. and Okumus, B. (2008), "Food tourism as a viable market segment. It's all how you cook the numbers!", Journal of Travel and Tourism Marketing, Vol. 25 No. 2, pp. 137-148.

Morrison, L.J., Colman, A.M. and Preston, C.C. (1997), "Mystery customer research. Cognitive processes affecting accuracy", Journal of the Market Research Society, Vol. 39, pp. 349-361.

Muskat, B., Hörtnagl, T., Prayag, G. and Wagner, S. (2019), "Perceived quality, authenticity, and price in tourists' dining experiences. Testing competing models of satisfaction and behavioral intentions", Journal of Vacation Marketing, Vol. 25 No. 4, pp. 480-498.

Namkung, Y. and Jang, S. (2007), "Does food quality really matter in restaurants? Its impact on customer satisfaction and behavioral intentions", Journal of Hospitality and Tourism Research, Vol. 31 No. 3, pp. 387-409.

Namkung, Y. and Jang, S. (2008), "Are highly satisfied restaurant customers really different? A quality perception perspective”, International Journal of Contemporary Hospitality Management, Vol. 20 No. 2, pp. 142-155.

Nguyen, Q., Nisar, T.M., Knox, D. and Prabhakar, G.P. (2018), "Understanding customer satisfaction in the UK quick service restaurant industry", British Food Journal, Vol. 120 No. 6, pp. 1207-1222.

Njite, D., Njoroge, J., Parsa, H., Parsa, R. and van der Rest, J.P. (2015), "Consumer patronage and willingness-to-pay at different levels of restaurant attributes: a study from Kenya", Research in Hospitality Management, Vol. 5 No. 2, pp. 171-180.

Oliver, R.L. (2014), Satisfaction: A Behavioral Perspective on the Consumer, Routledge, New York.

Parasuraman, A., Zeithaml, V.A. and Berry, L.L. (1988), "SERVQUAL. A multiple-item scale for measuring consumer perceptions of service quality", Journal of Retailing, Vol. 64 No. 1, pp. 12-40.

Parasuraman, A., Zeithaml, V.A. and Malhotra, A. (2005), "E-S-QUAL. A multiple-item scale for assessing electronic service quality", Journal of Service Research, Vol. 7 No. 3, pp. 213-233. 
Park, J.-Y. and Jang, S. (2014a), "Revisit and satiation patterns: are your restaurant customers satiated?", International Journal of Hospitality Management, Vol. 38, pp. 20-29.

Park, J.-Y. and Jang, S. (2014b), "Why do customers switch? More satiated or less satisfied", International Journal of Hospitality Management, Vol. 37, pp. 159-170.

Pikkemaat, B. and Zehrer, A. (2016), "Innovation and service experiences in small tourism family firms", International Journal of Culture, Tourism and Hospitality Research, Vol. 10 No. 4, pp. 343-360.

Pikkemaat, B., Peters, M. and Bichler, B.F. (2019), "Innovation research in tourism: research streams and actions for the future", Journal of Hospitality and Tourism Management, Vol. 41, pp. 184-196.

Podsakoff, P.M., MacKenzie, S.B., Lee, J.-Y. and Podsakoff, N.P. (2003), "Common method biases in behavioral research. A critical review of the literature and recommended remedies", Journal of Applied Psychology, Vol. 88 No. 5, pp. 879-903.

Preacher, K.J. and Hayes, A.F. (2008), "Contemporary approaches to assessing mediation in communication research", in Hayes, A.F., Slater, M.D. and Snyder, L.B. (Eds), The Sage Sourcebook of Advanced Data Analysis Methods for Communication Research, Sage Publ, Los Angeles, CA, pp. 13-54.

Psomas, E.L. and Jaca, C. (2016), "The impact of total quality management on service company performance. Evidence from Spain", International Journal of Quality and Reliability Management, Vol. 33 No. 3, pp. 380-398.

Raajpoot, N.A. (2002), “TANGSERV”, Journal of Foodservice Business Research, Vol. 5 No. 2, pp. 109-127.

Richardson, S., Lefrid, M., Jahani, S., Munyon, M.D. and Rasoolimanesh, S.M. (2019), "Effect of dining experience on future intention in quick service restaurants", British Food Journal, Vol. 121 No. 11, pp. 2620-2636.

Ringle, C.M., Wende, S.J.-M. and Becker (2015), "SmartPLS 3", available at: www.smartpls.com (accessed 5 June 2020).

Ryu, K. and Jang, S. (2008), "DINESCAPE. A scale for customers' perception of dining environments", Journal of Foodservice Business Research, Vol. 11 No. 1, pp. 2-22.

Ryu, K., Lee, H.-R. and Gon Kim, W. (2012), "The influence of the quality of the physical environment, food, and service on restaurant image, customer perceived value, customer satisfaction, and behavioral intentions", International Journal of Contemporary Hospitality Management, Vol. 24 No. 2, pp. 200-223.

Sester, C., Deroy, O., Sutan, A., Galia, F., Desmarchelier, J.F., Valentin, D. and Dacremont, C. (2013), "'Having a drink in a bar". An immersive approach to explore the effects of context on drink choice", Food Quality and Preference, Vol. 28 No. 1, pp. 23-31.

Shahzadi, M., Malik, S.A., Ahmad, M. and Shabbir, A. (2018), "Perceptions of fine dining restaurants in Pakistan", International Journal of Quality and Reliability Management, Vol. 35 No. 3, pp. 635-655.

Stevens, P., Knutson, B. and Patton, M. (1995), "DINESERV. A tool for measuring service quality in restaurants", The Cornell Hotel and Restaurant Administration Quarterly, Vol. 36 No. 2, pp. 56-60.

Sulek, J.M. and Hensley, R.L. (2004), "The relative importance of food, atmosphere, and fairness of wait”, Cornell Hotel and Restaurant Administration Quarterly, Vol. 45 No. 3, pp. 235-247.

Teixeira, J., Patrício, L., Nunes, N.J., Nóbrega, L., Fisk, R.P. and Constantine, L. (2012), "Customer experience modeling. From customer experience to service design", Journal of Service Management, Vol. 23 No. 3, pp. 362-376.

Tucker, R.B. (1991), "Ten driving forces of change”, Canadian Manager, Vol. 16 No. 2, pp. 16-17.

Wiele, T.V.D., Hesselink, M. and Iwaarden, J.V. (2005), "Mystery shopping. A tool to develop insight into customer service provision”, Total Quality Management and Business Excellence, Vol. 16 No. 4, pp. 529-541.
Role of quality for revisits in restaurants

\section{$+$}


JHTI

4,3

366
Wilson, A.M. (1998), "The use of mystery shopping in the measurement of service delivery", The Service Industries Journal, Vol. 18 No. 3, pp. 148-163.

WKO (2020), "Steps for setting up a business. business start-up glossary", available at: https://www. wko.at/site/mehrsprachige_info/Steps_for_setting_up_a_business__business_startup_ glossary.html (accessed 9 June 2020).

Yuksel, A., Yuksel, F. and Bilim, Y. (2010), "Destination attachment. Effects on customer satisfaction and cognitive, affective and conative loyalty", Tourism Management, Vol. 31 No. 2, pp. 274-284.

Zeithaml, V.A. (1988), "Consumer perceptions of price, quality, and value. A means-end model and synthesis of evidence", Journal of Marketing, Vol. 52 No. 3, pp. 2-22. 
Appendix

\begin{tabular}{|c|c|c|}
\hline Dimensions and adapted sources & Items & \\
\hline $\begin{array}{l}\text { Atmosphere } \\
\text { Physical facilities, equipment and }\end{array}$ & $\begin{array}{l}\text { The atmosphere is pleasant } \\
\text { The areas are thoroughly clean }\end{array}$ & 367 \\
\hline $\begin{array}{l}\text { appearance of people Sulek and } \\
\text { Hensley (2004) }\end{array}$ & The other guests contributed to my well-being & \\
\hline Reliability & All ordered drinks were served quickly and perfectly & \\
\hline Ability to perform the promised & Delivery of all ordered drinks and food left nothing to be desired & \\
\hline $\begin{array}{l}\text { service dependably and accurately } \\
\text { Lee and Cheng (2018) }\end{array}$ & The entire order was placed quickly and easily & \\
\hline $\begin{array}{l}\text { Lee and Cheng (2018) } \\
\text { Responsiveness }\end{array}$ & $\begin{array}{l}\text { I was able to order immediately after receiving the drinks/menu } \\
\text { I was immediately noticed }\end{array}$ & \\
\hline $\begin{array}{l}\text { Responsiveness } \\
\text { Willingness to help customers and }\end{array}$ & $\begin{array}{l}\text { I was immediately noticed } \\
\text { The welcome was very friendly }\end{array}$ & \\
\hline $\begin{array}{l}\text { provide prompt service Getty and } \\
\text { Getty (2003) }\end{array}$ & I was immediately offered a suitable place/table & \\
\hline Attentiveness & The attentive nature of the staff stimulated increased consumption & \\
\hline Individualized attention toward & The staff literally read the wishes from my eyes & \\
\hline customers Albacete-Sáez et al. (2007) & $\begin{array}{l}\text { The staff asked if everything was for the best } \\
\text { I felt warmly and professionally looked after during the whole visit } \\
\text { My waiter/waitress was especially attentive during the whole visit }\end{array}$ & \\
\hline $\begin{array}{l}\text { Food quality } \\
\text { Offered variety and tasty food }\end{array}$ & $\begin{array}{l}\text { For this type of restaurant, the range of drinks and food leaves nothing } \\
\text { to be desired }\end{array}$ & Ta \\
\hline Namkung and Jang (2007) & $\begin{array}{l}\text { The sensory quality of food and beverages was excellent } \\
\text { The price/performance ratio for the food/drinks offered is excellent }\end{array}$ & $\begin{array}{r}\text { SQ factors and items; } \\
\text { all items were } \\
\text { evaluated on a Likert }\end{array}$ \\
\hline Revisit & Based on all my experiences I would visit the restaurant again & \\
\hline $\begin{array}{l}\text { Degree of intent to revisit Kivela et al. } \\
\text { (1999), Getty and Thompson (1995) }\end{array}$ & $\begin{array}{l}\text { I would recommend the restaurant because of the service experience } \\
\text { I would recommend this place because of the quality of the food/drinks }\end{array}$ & $\begin{array}{l}1=\text { "strongly disagree" } \\
\text { to } 5=\text { "strongly agree" }\end{array}$ \\
\hline
\end{tabular}


$\underset{4,3}{\mathrm{JHTI}}$

368



Table A2.

Descriptives and correlations






\begin{tabular}{|c|c|c|c|c|c|}
\hline & $\begin{array}{l}\text { Substantive } \\
\text { FL }\end{array}$ & $R 1^{2}$ & $\begin{array}{l}\text { Method } \\
\text { FL }\end{array}$ & $R 2^{2}$ & $\begin{array}{l}\text { Role of quality } \\
\text { for revisits in }\end{array}$ \\
\hline \multicolumn{6}{|l|}{ Reliability } \\
\hline All ordered drinks were served quickly and perfectly & $0.833 * * *$ & 0.694 & -0.066 & 0.004 & \\
\hline $\begin{array}{l}\text { Delivery of all ordered drinks and food left nothing to be } \\
\text { desired }\end{array}$ & $0.622 * * *$ & 0.387 & 0.144 & 0.021 & \\
\hline The entire order was placed quickly and easily & $0.889 * * *$ & 0.790 & -0.107 & 0.011 & 369 \\
\hline $\begin{array}{l}\text { I was able to order immediately after receiving the drinks/ } \\
\text { menu }\end{array}$ & $0.722 * * *$ & 0.521 & 0.042 & 0.002 & \\
\hline \multicolumn{6}{|l|}{ Attentiveness } \\
\hline $\begin{array}{l}\text { The attentive nature of the staff stimulated increased } \\
\text { consumption }\end{array}$ & $0.989 * * *$ & 0.978 & $-0.258 * * *$ & 0.005 & \\
\hline The staff literally read the wishes from my eyes & $0.855^{* * *}$ & 0.731 & -0.072 & 0.050 & \\
\hline The staff asked if everything was for the best & $0.954 * * *$ & 0.910 & -0.224 & 0.174 & \\
\hline $\begin{array}{l}\text { I felt warmly and professionally looked after during the } \\
\text { whole visit }\end{array}$ & $0.447 * * *$ & 0.200 & $0.417^{*}$ & 0.009 & \\
\hline $\begin{array}{l}\text { My waitress/waiter was especially attentive during the } \\
\text { whole visit }\end{array}$ & $0.771 * * *$ & 0.594 & $0.096^{* * *}$ & 0.005 & \\
\hline \multicolumn{6}{|l|}{ Responsiveness } \\
\hline I was immediately noticed & $0.937 * * * *$ & 0.878 & -0.121 & 0.015 & \\
\hline The welcome was very friendly & $0.788^{* * * *}$ & 0.621 & -0.049 & 0.002 & \\
\hline I was immediately offered a suitable place/table & $0.722 * * *$ & 0.521 & $0.166^{* * *}$ & 0.028 & \\
\hline \multicolumn{6}{|l|}{ Atmosphere } \\
\hline The atmosphere is pleasant & $0.659 * * *$ & 0.434 & 0.071 & 0.005 & \\
\hline The areas are thoroughly clean & $0.644^{* * * *}$ & 0.415 & 0.017 & 0.000 & \\
\hline The other guests contributed to my well-being & $0.873 * * *$ & 0.762 & -0.075 & 0.006 & \\
\hline \multicolumn{6}{|l|}{ Food quality } \\
\hline $\begin{array}{l}\text { For this type of restaurant. the range of drinks and food leaves } \\
\text { nothing to be desired }\end{array}$ & $0.842 * * *$ & 0.709 & -0.087 & 0.008 & \\
\hline The sensory quality of food and beverages was excellent & $0.748 * * * *$ & 0.560 & 0.076 & 0.006 & \\
\hline $\begin{array}{l}\text { The price/performance ratio for the food/drinks offered is } \\
\text { excellent }\end{array}$ & $0.695 * * *$ & 0.483 & 0.005 & 0.000 & \\
\hline \multicolumn{6}{|l|}{ Revisit } \\
\hline $\begin{array}{l}\text { I would definitely recommend the restaurant because of the } \\
\text { service experience }\end{array}$ & $1.048 * * *$ & 1.098 & $-0.141^{* * * *}$ & 0.154 & \\
\hline $\begin{array}{l}\text { I would definitely recommend this place because of the quality } \\
\text { of the food/drinks }\end{array}$ & $0.476^{* * *}$ & 0.227 & $0.393^{* * *}$ & 0.047 & \\
\hline Based on all my experiences I would visit the restaurant again & $1.083 * * *$ & 1.173 & $-0.216^{* *}$ & 0.020 & \\
\hline Average & 0.79 & 0.65 & 0.001 & 0.03 & Common method bias \\
\hline \multicolumn{5}{|l|}{ Note(s): $* p<0.05, * * p<0.01, * * * p<0.001$} & \\
\hline
\end{tabular}

\section{Corresponding author}

Bernhard Fabian Bichler can be contacted at: bernhard.bichler@uibk.ac.at

For instructions on how to order reprints of this article, please visit our website:

www.emeraldgrouppublishing.com/licensing/reprints.htm

Or contact us for further details: permissions@emeraldinsight.com 